\title{
Sustainable Development and Green Buildings
}

\section{Održivi razvoj i zelena gradnja}

\author{
Review paper • Pregledni rad \\ Received-prispjelo: 17. 2. 2012. \\ Accepted-prihvaćeno: 15. 11. 2012. \\ UDK: $630 * 833.1$ \\ doi:10.5552/drind.2013.1205
}

\begin{abstract}
Global sustainability goals have led to the development of the green building movement. The Green Building Program, stemming from the movement, has had unprecedented success as it provides a quantifiable metric to people's efforts towards sustainable development. Sustainable development and green buildings are often used interchangeably. Although, sustainable development and green buildings are related, they are not the same. This paper provides an overview of how green building relates to sustainable development practices. Sustainability also governs decisions concerning building materials. A comprehensive explanation of what constitutes a green building material is discussed and how renewable material like wood fare in the deciding criteria. There are many green building rating systems in place. United States Green Building Council administered Leadership in Energy and Environment Design (LEED) is the global market leader in the rating systems. LEED is a commendable and grand effort in moving towards sustainable development by converting the built environment green. However, it does have certain pitfalls and challenges. Some of these challenges are with respect to policies on material selection and performance monitoring. The materials used in a project are considered at a common starting point and no consideration is given to the life cycle performance of the material. Statements concerning sustainability require validation, and Life Cycle Analysis (LCA) is a tool that can provide such validity. This paper presents how beneficial it can be, when included, in the bigger scheme of green building rating systems and introduces an integrated design concept for green buildings.
\end{abstract}

Key words: LEED, life cycle analysis, wood

SAŽETAK • Ciljevi održivosti društva i građana svijeta doveli su do razvoja pokreta zelene gradnje. Programi zelene gradnje, koji proizlaze iz pokreta, imali su neviđen uspjeh jer su osiguravali mjerljive veličine za uspješnost u naporima za održivi razvoj. Održivi razvoj i zelena gradnja često se upotrebljavaju u istom značenju. Iako su održivi razvoj i zelena gradnja povezani, oni nisu isto. U ovom je radu dan pregled kako se zelena gradnja odnosi prema praksi održivog razvoja. Održivost također utječe na odluke koje se odnose na materijal za gradnju. U radu se daje opsežno objašnjenje što je to zeleni građevni materijal se te navodi kako je obnovljivi materijal poput drva često među odlučujućim kriterijima pri gradnji. Postoje mnogi rejting sustavi zelene gradnje. Savjet za zelenu gradnju SAD-a upravljao je skupinom Vodstvo u energetici i zaštiti okoliša (LEED), koja je globalni tržišni lider u rejting sustavima. LEED skupina simbolizira vrlo pohvalan i velik trud u kretanju prema održivom razvoju pretvaranjem izgrađenog okoliša u zeleno. No tu su i neke zamke i izazovi. Neki od tih izazova odnose se na pravila odabira materijala i praćenje učinaka gradnje. Materijali koji se koriste u projektu razmatrani su s obzirom na zajedničko polazište, no nije razmatran i njihov životni ciklus. Izjave o održivosti zahtijevaju dokaz valjanosti, a analiza životnog ciklusa (LCA) alat je koji može dati takav dokaz. Rad pokazuje kako uključivanje takve analize u većim shemama rejting sustava zelene gradnje može biti korisno, kao i uvođenje integriranog koncepta dizajna zelenih zgrada.

Ključne riječi: LEED, analiza životnog ciklusa, drvo

\footnotetext{
${ }^{1}$ Authors are assistant professor and professor at Department of Wood Science and Engineering, Oregon State University, Corvallis, Oregon, USA. ${ }^{2}$ Author is research associate at Andrej Marušič Institute, University of Primorska, Koper and at ILTRA d.o.o., Ljubljana, Slovenia. Autori su docent i profesor Odjela znanosti o drvu i inženjerstva Sveučilišta u Oregonu, Corvallis, Oregon, SAD. ${ }^{2}$ Autorica je znanstvenica Instituta Andrej Marušič, Sveučilište Primorska, Koper, i ILTRA d.o.o., Ljubljana, Slovenija.
} 


\section{INTRODUCTION}

\section{UVOD}

Climate change and its disastrous consequences are stimulating the transformation towards a sustainable development, with its increasing economic efficiency, protection and restoration of ecological systems and improvement of human well-being. The maintenance of natural resources is a subject that often appears when sustainable development is considered. In addition, with increasing world population and economic development of various nations, the strain on resources is increasing. As economic development and environment are linked, the realization has set in to conserve energy and resources. Globally, infrastructure and building construction consumes $60 \%$ of the raw materials extracted from the Earth (Bribian et al., 2011, MMSD, 2002). From this volume, building accounts for $40 \%$, in other words $24 \%$ of these global extractions. In the US, with $4 \%$ of world's population, the consumption of resources is at a staggering $25 \%$ of total resources available in the world (Teller and Bergman 2010). A majority of these resources (60\% according to USGBC) are consumed in the building industry. In Europe, the per capita mineral extractions for buildings are approximately 4.8 tons per year (Wadel, 2009) Consumption of non-renewable and non-replenishable minerals will be detrimental to the environment and will have catastrophic effect on humans. In addition to that, energy consumption during and in use of building is enormous. In the US, the built environment accounts for $65 \%$ of all energy consumption (USGBC 2010). In the European Union (EU) the corresponding number is $42 \%$ (Nelson 2002). In addition, carbon dioxide $\left(\mathrm{CO}_{2}\right)$ emissions from the built environment accounts for roughly $35-40 \%$ of total emissions, both in the US as well as in the EU (Environmental Information Administration 2008, Nelson 2002). Not only do buildings consist of a multitude of products, and therefore technical and biological nutrients, they also have an important and wide-ranging impact on water and energy cycles, air quality (indoor and outdoor), and fauna and flora, as well as on social and economic factors. The increased use of resources that cause pollution and emissions, highlight the need to save and conserve energy for sustainable development.

In engineering, sustainable design is a design ideology, which harbors the notion of sustainable human and societal development. Sustainable development can be defined in various ways. Every individual will approach the issue of sustainability in a different manner depending upon various factors, such as, sustainability goals, background, awareness, and economic conditions. Sustainability is providing opportunity of development to the future generation, in terms of resources. One of the key aspects in sustainability is sustainable construction. Sustainable construction practices are such that they are based on ecological principles, with no environmental impacts, have a closed material loop, and have full integration into the landscape after the service life of the structure is over. The concept of green build- ings is the measure of our efforts in attaining that idealistic sustainable construction practices. According to Environmental Protection Agency (EPA) in the US, Green Building is the "practice of creating structures and using processes that are environmentally responsible and resource-efficient throughout a building life-cycle from siting to design, construction, operation, maintenance, renovation, and deconstruction." This definition has evolved over the years. "Green Buildings" is an ever evolving, dynamic term. Green Building is the status of our efforts in attaining sustainability in construction practices. As technology evolves and new materials are developed, the status of our efforts are also changing. Hence, the essence of green buildings is changing. The aim of this paper is to discuss sustainability with respect to green buildings, its importance in one of the world's leading Green Building program - Leadership in Energy and Environmental Design (LEED) certification from the perspective of sustainable material selection, and governing policies in LEED. Furthermore, the role of life cycle assessment (LCA) in assessing the sustainability claims of green buildings and building materials is introduced. Moreover, the potential for including LCA in the scheme of Green Building rating system is critically evaluated.

\section{SUSTAINABILITY WITH RESPECT TO} BUILDING MATERIALS

\section{ODRŽIVOST S OBZIROM NA MATERIJALE ZA GRADNJU}

Sustainability is increasingly becoming a key consideration of building practitioners with the goal of increasing economic efficiency, protecting, and restoring ecological systems and improving human well-being. To achieve sustainability, the following objectives should be met:

1. Minimize consumption of matter and energy;

2. Reusability and recyclability of the material;

3. Human satisfaction;

4. Minimum environmental impacts and embodied energy.

It is important to minimize the consumption, as while a material is consumed, its chances for future use are diminishing; hence, its potential utility to future generation is lost (Roberts, 1994). Another aspect of minimizing the consumption is either reusing the same material or recycling the material to mold into a different or similar building product. This also ties into the third criteria i.e., meeting a certain level of end-user satisfaction (Pearce at al., 1995). Trade-offs are inevitable when deciding on a material, and mostly are between resource consumption and human satisfaction. Human satisfaction level also changes with time and is correlated to various external factors, such as, costs, ensuring human comfort, safety and enriching the human spirit (Day, 1990). Human satisfaction level is also driven by the sustainability goal that in turn dictates the material selection process. Addressing the need of human satisfaction is very important. Another important aspect of material selection is its environ- 
mental costs and energy associated at various steps of its manufacturing process. However, to define a green material, numerous factors have to be considered.

\subsection{Evaluation of building materials on} "greenness"

2.1. Ocjena materijala za gradnju kao "zelenoga"

The most general criteria for evaluating building materials are resource management, pollution or indoor environmental quality (IEQ), and performance (Milani, 2005; Spiegel and Meadows, 2006). The resources used by a material include all the components and energy used to extract, process, transport, use, and dispose/ recycle it. The energy used to produce it or process it to usable form, known as embodied (or embedded) energy can be particularly large for building materials. Pollution includes all the emissions of the mines and factories used to produce the material, as well as the emissions of use - formaldehyde and emissions from products used to clean and maintain the material - along with the pollution resulting from its final incineration or land-filling (Milani, 2005). Performance refers to how well the material does its intended job. Materials with low durability, no matter how benignly produced, can hardly qualify as green. Durability is defined as the ability of a building or any of its components to perform the required functions in a service environment over a period of time without unforeseen cost for maintenance or repair. Wood is durable material, which has to be accompanied with appropriate building applications and design. The natural durability of wood has been proven by the multitude of buildings that have stood for centuries. While wood natural bio-based attributes make it a sustainable building material, it also makes wood vulnerable to decay and wood destroying insects. Proper design, installation and detailing are critical to ensure long-term durability. When wood is used in exposed applications, or in areas where it is subjected to moisture and insects, it must be protected with mechanical barriers, coatings and, in some instances, preservative treatments. For materials like insulation, performance goes beyond durability, since good thermal performance, for example, can actively save resources and energy.

These three evaluation categories, resources, performance, and pollution overlap considerably. Consider a sheathing material, for example the performance of that material, will influence the resources and energy they use in operation. Construction materials live much longer than most other materials (Milani, 2005; Wadel, 2009). Approximately, $60 \%$ of the materials extracted out of earth's crust end up in the built environment (Wadel, 2009; Bribian et al., 2011) and they have a life cycle, mostly related to the time when the building is in operation. This tends to make durability and performance somewhat more important than for many other kinds of products. Figure 1, compiled from inputs from Malin (1999, 2002), Milani (2005) and Spiegel and Meadows (2006), presents various phases of material, which are the base of evaluations. "Greenness" of a material is evaluated on four distinct levels:

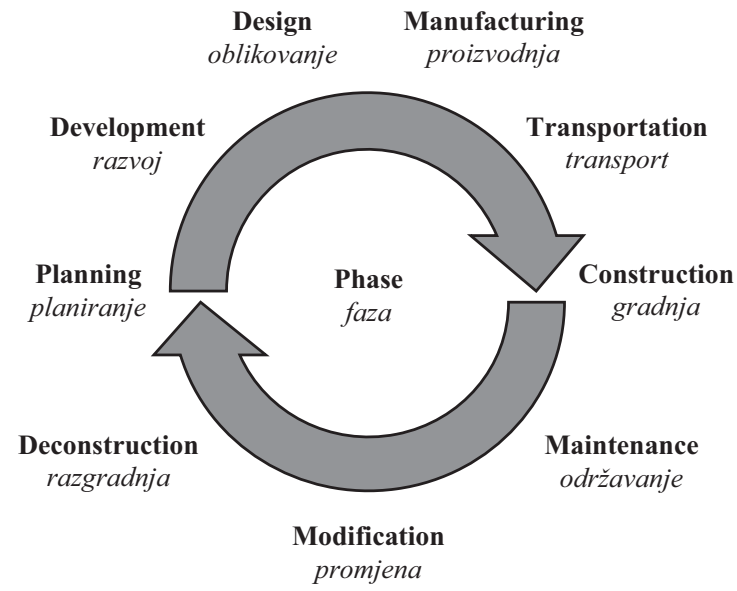

Figure 1 Various phases of a material life cycle

Slika 1. Faze životnog ciklusa materijala

- Raw-Material Phase (resource limitation, resource extraction, transportation);

- Manufacturing Level (waste reduction, pollution prevention, recycled content, embodied energy reduction, use of natural materials);

- Operation level (reduction in construction waste, energy efficiency, longer life/ durability, occupant health, water treatment/conservation, use of non-toxic or lesstoxic materials, renewable energy systems);

- Disposal (reusability, recyclability, biodegradability).

\section{GREEN BUILDING RATING SYSTEMS}

\section{REJTING SUSTAVI ZELENE GRADNJE}

The green building movement addresses a broad array of areas such as energy efficiency, water management, material production, construction issues, occupant health quality, air quality management, recycling, reusability, and waste management (Bowyer, 2008). This vast array of its coverage could be one of the reasons for its unprecedented success. Currently there are more than 40 green building programs in the US. In the residential sector, many independent organizations led an initiative in their local jurisdiction and municipalities across the US. Some examples of these are the green building movement in Denver, Colorado; Kitsap County and King County, Washington; the Baltimore suburban builders association; the Earth craft houses program in Atlanta; Austin Green builder program, and Wisconsin green built program. The National Association of Homebuilders (NAHB) was proactive and took note of these increasing initiatives towards green construction, and as a result issued guidance available to its 800 state and local associations, educating and informing them how to create their own green building program. Encouraged by its enormous success and a need for standardization, NAHB designed its own green building program in 2008, called the National Green Building Program (NAHB 2010). Since its inception, it has emerged to be the market leader in the residential sector. However, in the commercial arena, the market leader is the US Green Building Council (USGBC) administered program called the Leadership in Energy and Environmental De- 
sign (LEED) followed by Green Globes. Since foundation of the NAHB rating system, LEED has also diversified itself in an effort to enter the residential sector. To earn certification under the LEED program, a building must meet certain prerequisites and performance benchmarks within each category.

The World Green Building Council recognizes 25 countries in Europe that have green building councils. With its strong focus on zero net resource consumption and passive solutions, Europe is widely recognized as a global leader in minimizing the use of resources and energy. The United Kingdom was the first country to develop a major green building rating system called the Building Research Establishment Environmental Assessment (BREEAM). Germany and France have their own green building rating systems. In Eastern Europe, LEED is also gaining popularity (Sinha and Kutnar, 2012).

\subsection{LEED rating system}

\subsection{Rejting sustav LEED}

The LEED rating system is administered by United States Green Building Council (USGBC). LEED is a voluntary rating system to ensure a superior environmental performance of a building over its life time. LEED was developed to evaluate the performance of construction and design from a standpoint of sustainability in 1998 for commercial constructions. Since its inception, LEED has evolved and improved through several revisions. LEED 2009 is the current version, while discussions are currently underway for LEED 2012. LEED 2009 contains the following specific rating systems: 1) New Construction (NC); 2) Existing Buildings: Operations and Maintenance; 3) Commercial Interiors; 4) Core and Shell; 5) Retail; 6) Healthcare; 7) Homes; and 8) Neighborhood Development. Each of the rating systems is composed of 100 points, which are divided among five categories: Sustainable Sites (26); Water Efficiency (10); Energy and Atmosphere (35); Materials and Resources (14); and Indoor Environmental Quality (15). Additionally, up to 10 bonus points are possible through innovative design and consideration of regional priorities. Each category in LEED 2009 has certain prerequisites that are mandatory for all projects and are not eligible for points. The points are then distributed across major categories and are assigned in a progressive way for incremental level of documented efforts to increase environmental performance. The LEED system rates buildings at four levels - certified, silver, gold, and platinum, with the following credit requirements:

- Certified - 40 - 49 points

- Silver - 50 - 59 points

- Gold - 60 - 79 points

- Platinum - 80 points and above

Currently, the LEED rating system is a nationally accepted benchmark for design, construction and operation of high-performance green buildings and is used to evaluate a significant portion of new construction within the United States. In the commercial arena in the United States, LEED is the market leader, with $90 \%$ of all certi- fied buildings being LEED certified. It can be argued that the LEED system is also a global leader in green building. The LEED International Roundtable is composed of representatives from 21 countries who work to provide global consistency in regional approaches to green building. Each of these 21 countries utilizes LEED rating systems that are catered to the local conditions in their country. Additionally, LEED has registered projects in 133 countries. The percentage of new construction projects evaluated by LEED (for New Construction) has markedly increased throughout the last decade, as various stakeholders recognize the need to validate their achievements for sustainable construction. The green building concept and sustainable design are growing phenomenon in engineering, which has an unprecedented growth rate and acceptability. In 2006, studies showed that about $20 \%$ of the designers have been involved in projects that have resulted in LEED certification as opposed to only $10 \%$ in 2003 (BDC, 2011). It is projected that by the end of $2013,94 \%$ of the current architectural and engineering firms would be extensively working on green projects (Bernstein and Bowerbank, 2008). In the future, it is speculated that green building rating systems will move towards performance-based systems and have a performance monitoring protocol in place. The fact that the energy supply and resources are diminishing; coupled with the increased awareness in people to contribute towards sustainability is helping drive this rapid growth in green buildings. People like to see their efforts validated by an agency and USGBC through LEED is providing that. Furthermore, despite dominance of Buildings Research Establishment Environmental Assessment Methodology (BREEAM) in the European green building performance market, LEED is gaining some traction. Various projects all over Europe are adopting LEED measures. Several buildings have been already LEED certified in Italy, England, Poland, the Czech Republic, Bulgaria, and Portugal.

\subsection{Questionable ratings in LEED \\ 3.2. Dvojbeni rejtinzi u LEED-u}

\subsubsection{LEED - Materials}

3.2.1. LEED - materijali

The USGBC, although a grand and comprehensive effort towards sustainable design, has certain pitfalls in terms of how it rates the materials. There are provisions in LEED and other primary green building programs, which could result in significant negative impact on wood and wood products as a building material (Bowyer, 2008). The LEED rating system rates the material at the same level while being used in the building. All materials are considered at an equal footing and their life history does not have an impact on the rating credits. Materials like, concrete and wood are considered equal. However, life cycle analysis have shown that wood has less embodied energy than concrete or steel because it is a biological renewable material (Puettman et al., 2005), while the raw materials to make cement and then concrete is a product of energy intensive mining (PCA, 2002; van Oss and Padovani, 2002; Rajendran and Gambatese, 2007). Steel is preferred over wood and concrete, because of its recyclability and recycled content (USG- 
$\mathrm{BC}, 2009)$. Steel, although it is recyclable, has higher environmental impacts than wood because the raw material has to be mined and then steel has to be extracted in a furnace (IISI, 2000). Many experts (Bowyer, 2008) consider this viewpoint, by which more importance is given to steel, as a serious error from an environmental standpoint.

LEED assigns extra credit for materials that are "rapidly renewable" (LEED-NC, 2009). The criterion of rapid renewability with respect to wood is 10-year turn around period. For trees with a smaller rotation time of 10 years or less, those credits can be attained. However, for longer rotation crops valuable credits cannot be obtained. Wood is a renewable material, with some trees having a smaller rotation cycle and some trees having a higher rotation period. Bamboo, for e.g., is a rapidly growing tree as compared to maple and hence, so bamboo flooring is preferred over maple flooring in LEED. The scientific background of this preference has been heavily challenged (Bowyer, 2007) and there is ongoing debate as to whether to change the category of "rapidly renewable" to "renewable" (YPFPG, 2008). This will give wood as a building material clear advantage as it is a renewable material. Besides, wood is causing less emissions of $\mathrm{CO}_{2}$ and generates less waste compared to the alternative materials (Petersen and Solberg, 2005).

A challenge that LEED faces is to ensure that the wood coming into the project has been grown and harvested in a sustainable manner. Forest Certification ensures this. Forest Certification has a two-fold objective in the LEED program. It provides evidence that the wood has been grown and harvested in environmentally and socially responsible manner, and determines whether wood might qualify for credits as a "renewable" material. It will also ensure that wood harvested illegally (outside the US) will not receive any credits. There are many forest certification schemes prevalent in the US. Currently, Forest Stewardship Council (FSC) is the only one recognized by the USGBC (LEED-NC, 2009). Alternative programs, although similar in their efforts to promote responsible forest management, are not recognized. With FSC wood being limited, it is difficult to earn credits for certified wood. Moreover, it is only wood that requires external validation or certification, while other materials in LEED do not (LEED, 2009), despite social and environmental impacts associated with other materials (Bowyer, 2007, 2008).

\subsubsection{LEED - Performance}

\subsubsection{LEED - izvedba}

Besides its ambiguity in rating materials, the performance of the LEED program has also been challenged (Torcellini, 2004; Bowyer, 2008; Bribian et al., 2011). The LEED program is a not performance based rating system. Rather, it is a checklist of provision, which is supposed to ensure performance. There are no provisions for performance monitoring in LEED. As a result, a question is often posed - "Does the LEED program help in reducing energy consumption and improve energy performance of building?" The LEED program has been around long enough to assess the changes. Various studies have tried to answer this. Torcellini et al. (2004) conducted an overview of six sustainable buildings in the USA to compare the results to predicted energy savings. Analysis showed that all buildings performed worse than predicted, but all managed a substantial saving compared to a comparable code-compliant building. The deviation from the predicted savings was due to higher than expected occupant loads and systems not performing together as designed. Turner (2006) compared 11 buildings in the Cascadia Region, USA and found all buildings performed better than their baseline. In other words, buildings performed better than their non-green code-compliant counterparts. Fowler and Rauch (2008) investigated 12 Federal Buildings, all designed with energy conservation approach and found that they saved $25-30 \%$ more energy that similar US commercial buildings. Baylon and Storm (2008) examined the characteristics of LEED commercial buildings in the US Pacific Northwest, and compared them to regional non-LEED buildings. The mean energy use per floor area for the 12 LEED buildings was $10 \%$ lower than the 39 similar non-LEED buildings in the same region.

Diamond et al. (2006) investigated 21 LEEDcertified (LEED-NC Version 2.0/2.1) buildings using the modeled energy data for the as-designed and baseline building as submitted to the USGBC. On average, for the 18 buildings that had both simulated whole building design and actual energy use data, energy use was $1 \%$ lower than modeling predictions (which were $27 \%$ below baseline). However, there was large variability (standard deviation, s.d. $46 \%$ ), and some performed better than predicted, while others performed worse. Further, the number of LEED energy credits obtained in the certification did not correlate with the actual energy use per floor area. Newsham et al. (2009) reported similar results. The authors studied 100 LEED certified buildings, compared the results to commercial US buildings, and reported that LEED buildings used 18-39\% less energy per floor area than their conventional counterparts, confirmed by statistical analysis. However, 28-35 $\%$ of LEED buildings used more energy than their conventional counterparts. Similar to Diamond et al. (2006), Newsham et al. (2009) did not find any correlation between the certification level (Silver, Gold, Platinum) and the measured energy performance. Therefore, they recommended that although green buildings contribute to significant energy savings, more work is needed to define the scope of the rating systems and design a plan to be consistent at a generic level as well as at the individual building level.

\section{LIFE CYCLE ASSESSMENT (LCA) - POTENTIAL GREEN BUILDING RATING SYSTEM}

4. OCJENA ŽIVOTNOG CIKLUSA (LCA) POTENCIJALNI REJTING SUSTAV ZELENE GRADNJE

Life-cycle assessment (LCA) is a rational, quantified approach to determining specific environmental impacts of a product or system through its entire life cycle. 
As solutions are sought to reduce the impacts of buildings, LCA is seen as an objective measure for comparing building designs. LCA clearly has an important role to play in assessing the sustainability of green buildings and it is a valuable tool in decision-making.

Studies found LCA to have started in 1960s (Hunt et al., 1992), however, it gain prominence in the 1990s (Bribian et al., 2009). From the time, when LCA analysis was developed till today, numerous methodologies to classify, characterize, and normalize environmental effects have been developed. The most common, for example CML 2 (2000), IPCC Greenhouse gas emissions, Ecopoints 97 and Eco-indicator 99 (PRé Consultants, 2010), are focused on the following indicators: acidification, eutrophication, thinning the ozone layer, various types of ecotoxicity, air contaminations, usage of resources and greenhouse gas emissions. At first, LCA analysis was mostly focused on environmental effects like acidification and eutrophication, while more recently mostly on greenhouse gas emissions, which are also called carbon footprint. The carbon footprint is expressed in terms of the amount of emitted carbon dioxide or its equivalent of other greenhouse gases. In Europe, carbon footprint is gaining its importance and it can be expected that it will become necessary information accompanying products and services.

The LCA methodology involves four steps (Environmental, 1997; ISO 14040, 2006; Puettmann et al., 2010). The goal and scope definition step spells out the purpose of the study and its breadth and depth. The second step, Life Cycle Inventory (LCI) quantifies the environmental inputs and outputs associated with a product over its entire life cycle. Inventory analysis entails quantifying the inventory flows for a product system. Inventory flows include inputs of water, energy, and raw materials, and releases to air, land, and water. However, these inputs and outputs are not of great interest (Lippiatt, 1998). More important are their consequences, or impacts on the environment. Thus, the next LCA step, impact assessment (LCIA), characterizes these inventory flows in relation to a set of environmental impacts as identified in LCI. Finally, the interpretation step combines environmental impact in accordance with the goals of the study (Environmental, 1997).

For a product, the life cycle starts with procuring the raw material, primary processing, secondary processing or manufacturing, packaging, shipping and handling, installation, in-use energy consumption, maintenance, and end-of-life strategies. Figure 2 shows the various stages of a product lifecycle and system boundaries. LCA is performed at various stages (Figure 2). For example, Cradle-to-Gate refers to life cycle assessment from raw material stage to the point it is shipped out to the field. Similarly, cradle-to-grave involves LCA of all stages of the product or the material, starting from raw material procurement to end-of-life strategies. For buildings, the life cycle generally starts with extraction of raw resources from the natural environment or recovery of materials from a previous use. The raw resources are then manufactured into useable products, such as steel, concrete, etc. The finished

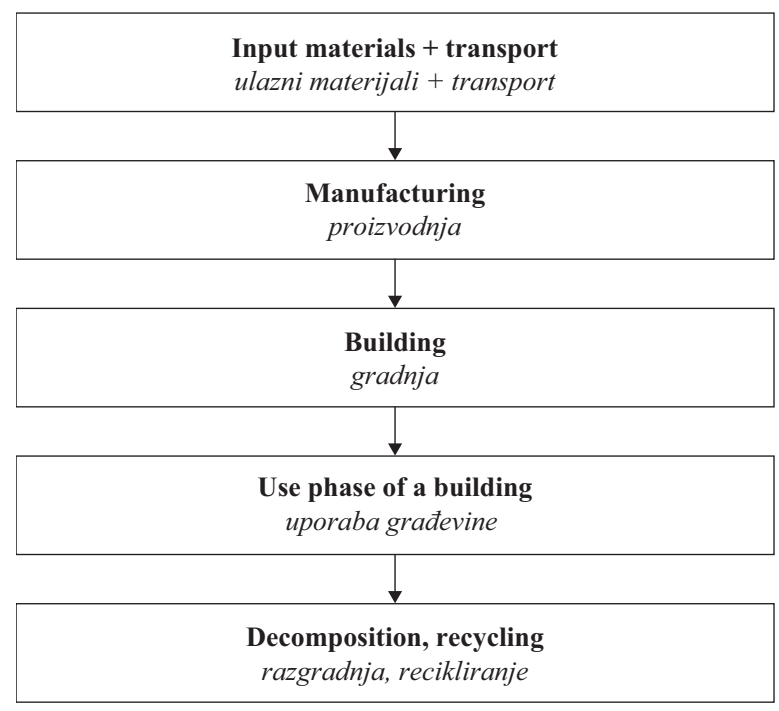

Figure 2 Simplified presentation of LCA variants, system boundaries

Slika 2. Pojednostavnjena prezentacija varijanti LCA, granice sustava

products are then shipped to the site consuming energy in the process. On the site, the products are assembled into a building. During the service life of the building, it consumes energy. In due course of time renovation or retrofit is performed on the building, which uses materials and energy. Finally, the building is removed/demolished and its materials disposed of either as construction waste or recycled for reuse. Each of these steps consumes energy and materials and produces waste. The purpose of the LCA quantifies how a building product or system affects the environment during each phase of its life. Examples of parameters that may be quantified include: energy consumption, resource use, greenhouse gas production, solid waste generation, and pollution generation.

The adoption of life-cycle approach to design, where not only current energy concerns are accounted for, but also long-term energy, environmental, and social impacts, should lead to an integrated approach to design. A building uses most of its energy during its service life, which is about $90 \%$ of the total life cycle energy (Citherlet and Defaux, 2007; Newsham et al., 2009). This is the stage where a structural engineer has least impact. However, as building energy use has become more efficient, the role of structural engineer has become more and more important. A structural engineer has primary input during the design, construction and end-of-life stages, where a significant energy reduction can result in buildings with less environmental impacts. A structural engineer, if involved in planning, can have significant impact in all aspects of the building life-cycle. Structural engineers must be forthright, educate themselves in LCA and sustainability so that they can be decision-makers, and be able to make their contribution to reducing the project's environmental impact (Webster, 2005).

As the influence of green building programs continues to increase and the field matures, the primary green building programs will shift to use of LCA as a 
means of using science and consistent methodology to inform green building decisions (Bowyer, 2008) and move towards an integrated design process, since the design of a building is a complex process involving multitudes of disciplines and expertise. However, transparent and standardized approach to LCA is needed to assess the ecological and environmental consequences of the use phase of the buildings. Namely, the values can differ significantly among different studies. The use of different input data, functional units, allocation methods, reference systems and other assumptions, complicates comparisons of LCA green building studies. To be sustainable in a holistic way, an integrated design process should be adopted. Each system or discipline in a project has some effect on another system in varying degrees. Moreover, the total environmental impact could be reduced by involving each aspect of the project from the onset. The first step is to form an integrated, multidisciplinary design team of owners, architects, structural engineers, civil engineers, geotechnical engineers, landscape designers, maintenance or operations staff, general contractor and key subcontractors, cost consultants, and end-use representatives. Green building construction must integrate building professionals, so that they work together for the common goal of sustainability. This integration must begin at the pre-design phase and continue through to post-occupancy, in order to optimize the building performance. Integrated design is a critical component in reducing costs in the construction of green buildings.

\subsection{Wood as a building material 4.1. Drvo kao građevni materijal}

Wood is a material of choice in many countries for residential and light commercial buildings. $90 \%$ of the residential buildings in the US are wood-frame construction. Japan is also not far behind. The use of wood in green buildings fits well with the previously mentioned criteria for green building materials. Wood is a renewable resource, manufactured in nature using a large quantity of solar energy. Hence, no fossil fuels are required for manufacturing of wood. When waste wood is burned, it provides an independent source of energy. Energy from waste wood is solar energy, which has been stored in the wood for a few years. As a result, the embodied energy of wood is miniscule as compared to other building materials. Wood can be recycled, but not in the extensive manner of materials like metals and glass. The production of wood is generally nonpolluting at all stages although there have been instances in the past with polluted sites from chemical preservative processes (Buchanan, 2006, 2010). Another reason for building in wood is the increase in the pool of carbon stored in wood and wood products. This is very important from a climate change standpoint. Green building programs do not give proper credit to wood and its low embodied energy (Bowyer, 2008). As a result wood products are often overlooked by architects, builders, and contractors. Within the green building sector, the wood industry must innovate and try to improve their market by creating a niche for new structural products.

\section{CONCLUSION}

\section{ZAKLJUČAK}

Sustainability is increasingly becoming a key consideration of building practitioners, policy makers, and industry alike, since the world is moving towards zero-energy construction. When buildings have net zero energy consumption, the effect of embodied energy and greenhouse gas emissions become important. A zero energy house can be built with different materials and construction methods that create different cumulative carbon footprint. Wood products can have very low or negative carbon footprint. Therefore, the utilization of wood, the most important renewable material, in all aspects of human existence appears to be the most effective way to optimize the use of resources and to reduce the environmental impact associated with mankind's activities. Typically, the use of wood products results in lower emissions and thus a lower overall environmental impact. However, to achieve sustainable development, certain criteria within a framework of economic, environmental and social systems must be followed. Only effective use of wood through the whole value chain from forest management and multiple use of forest resources through new wood and fiber-based materials and processing technologies to new end-use concepts, e.g. in the area of construction, can lead to sustainable development. Therefore, research, development and innovation related to "green" buildings should focus on LCA analysis in all product stages, from primary processing and use to disposal, and integrate knowledge and experience from various disciplines, engaging scientists from areas like engineering, material science, forestry, environmental science, architecture, marketing, and business. The activities should be oriented towards new product development from renewable materials, and utilization of the whole wood value chain, engineering solutions, and cradle2cradle concept.

\section{REFERENCES}

\section{LITERATURA}

1. Baylon, D.; Storm, P., 2008: Comparison of commercial LEED buildings and non-LEED buildings within the 2002-2004 Pacific Northwest commercial building stock, in: ACEEE Summer Study on Energy Efficiency of Buildings, American Council for an Energy-Efficient Economy (Washington DC, USA): 4-1, 4-12.

2. Bernstein, H.; Bowerbank, A., 2008: "Global Green Building Trends: Market Growth and Perspectives." Around the World. McGraw-Hill Construction; pp. 48.

3. Bowyer, J.L., 2008: The green Movement and the forest products industry. Forest Prod. J. 58(7/8): 6-13.

4. Bowyer, J.L., 2007: The green building programs-are they really green?. Forest Prod. J. 57(9): 6-17.

5. Bowyer, J.; Shmulsky, R.; Haygreen, J., 2007: Forest Products and Wood Science - an Introduction, 5th edition. Ames: Blackwell Publishing, 558 pp. 
6. Bribian, I.Z.; Uson, A.A.; Scarpellini, S., 2009: Life cycle assessment in buildings: State-of-the-art and simplified LCA methodology as a complement for building certification Ignacio. Build. Environ. 44: 2510-2520 http://dx.doi.org/10.1016/j.buildenv.2009.05.001.

7. Bribian, I.Z.; Capilla, A.V.; Uson, A.A., 2011: Life cycle assessment of building materials: Comparative analysis of energy and environmental impacts and evaluation of the eco-efficiency improvement potential. Build Environ 46: $1133-1140$

http://dx.doi.org/10.1016/j.buildenv.2010.12.002.

8. Buchanan, A.H., 2006: Can Timber Buildings Help Reduce Global CO2 Emissions? Proceedings, World Conference on Timber Engineering. Portland, Oregon, USA.

9. Buchanan, A.H., 2010: Energy and CO2 advantages of wood for sustainable buildings. Proceedings, World Conference on Timber Engineering. Riva-del-Garda, Italy.

10. Building Design and Construction (BDC), 2011: "Green Buildings and the Bottom Line.” Oak Brook, I.L. Build. Environ. 46: 1133-1140.

11. Citherlet, S.; Defaux, T., 2007: Energy and environmental comparison of three variants of a single family house during its whole life span. Build. Environ. 42: 591-598 http://dx.doi.org/10.1016/j.buildenv.2005.09.025.

12. Day, C., 1990: Places of the soul. Aquarian Press, San Francisco, CA.

13. Diamond, R.; Opitz, M.; Hicks, T.; Vonneida, B.; Herrera, S., 2006: Evaluating the energy performance of the first generation of LEED-certified commercial buildings, in: ACEEE Summer Study on Energy Efficiency in Buildings, American Council for an Energy-Efficient Economy (Washington DC, USA): 3-41, 3-52.

14. Fowler, K.M.; Rauch, E.M., 2008: Assessing green building performance: a post occupancy evaluation of 12 GSA Buildings, Pacific Northwest National Laboratory Report number PNNL-17393, 2008.

15. International Iron and Steel Institution (IISI), 2000: "Worldwide LCI database for steel industry products." IISI, Brussels, Belgium.

16. International Organization for Standardization (ISO), 1997: "Environmental management - Life cycle assessment - Principles and framework." ISO 14040, Geneva, Switzerland.

17. ISO 14040, 2006: Environmental management - Life cycle assessment - Requirements and guidelines.

18. James, S.; Lahti, T., 2004: The Natural Step for Communities: How Cities and Towns can Change to Sustainable Practices. Gabriola Island, BC: New Society Publishers

19. Kibert, C.J., 2004: Green Buildings: An overview of progress. J. Land Use 19(2): 491-502.

20. Lippiatt, B.C., 1998: BEES 1.0: Building for environmental and economic sustainability. Technical manual and user guide, NISTIR 6144, NIST, Gaithersburg, Md.

21. Malin, N., 1999: Environmentally Responsible Building Materials Selection. In C. J. Kibert (Ed.), Reshaping the Built Environment: Ecology, ethics, and environment. Washington DC/Covelo, California: Island Press.

22. Malin, N., 2002: Life-Cycle Assessment for Buildings: Seeking the Holy Grail. Environmental Building News, 11(3).

23. Matos, G.; Wagner, L., 1998: "Consumption of materials in the United States, 1900-1995.” Annu. Rev. Energy Environ. 23: 107-22 http://dx.doi.org/10.1146/annurev.energy.23.1.107.

24. Milani, B., 2005: Building materials in a green economy: Community-based strategies for dematerialization. $\mathrm{PhD}$ Dissertation, University of Toronto, Canada.
25. Mining, Minerals and Sustainable Development (MMSD), 2002: "Breaking new ground: The report of the Mining, Minerals, and Sustainable Development Project." Mining, Minerals, and Sustainable Development. (MMSD), Earthscan for International Institute for Environment Development (IIED) and World Business Council for Sustainable Development (WBCSD).

26. NAHB, 2010: National Association of Home Builders.

27. Nelson, W., 2002: Compressed Earth Blocks. In J. F. Kennedy, M. G. Smith \& C. Wanek (Eds.), The Art of Natural Building (pp. 138-142). Gabriola Island BC: New Society Publishers.

28. Newsham, G.R.; Mancini, S.; Birt, B.J., 2009: "Do LEED-certified buildings save energy? Yes, but...”. Energy Build. 41: 897-905 http://dx.doi.org/10.1016/j.enbuild.2009.03.014.

29. Pearce, A., Makarand, H.; Vanegas, J., 1995: “A Decision Support System for Construction Materials Selection Using Sustainability as a Criterion.” In: Proceedings of the 28th Annual Conference, National Conference of States on Building Codes and Standards. Albuquerque, New Mexico, November 1-4.

30. Petersen, A.K.; Solberg, B., 2005: Environmental and economic impacts of substitution between wood products and alternative materials: a review of micro-level anayses from Norway and Sweden. Forest Policy Econom. 7: 249-259 http://dx.doi.org/10.1016/S1389-9341(03)00063-7.

31. Portland Cement Association (PCA), 2002: Environmental life cycle inventory of Portland cement concrete. Appendix: Life cycle inventory of Portland cement manufacture. PCA, Skokie, IL.

32. PRé Consultants, 2010: Impact assessment methods. http://www.pre.nl/simapro/impact_assessment_methods. htm\#EP97.

33. Puettmann, M.E.; Wilson, J.B., 2005: Life-cycle Analysis of Wood Products: Cradle-to-gate LCI of Residential Wood Building Material. Wood Fiber Sci. 37: 18-29.

34. Rajendran, S.; Gambatese, J.A., 2007: Solid Waste Generation in Asphalt and Reinforced Concrete Roadway Life Cycles. J. Infrastruct. Sys. 13(2): 88-96 http://dx.doi.org/10.1061/(ASCE)1076-0342(2007)13:2(88).

35. Rees, W.E., 1990: The ecology of sustainable development. The ecologist 20(1): 18-23.

36. Roberts, D.V., 1994: Sustainable development - A challenge for the engineering profession. In Ellis, MD ed. The role of engineering in sustainable development. American Association of Engineering Societies, Washington DC: 44-61.

37. Spiegel, R.; Meadows, D., 2006: Green Building Materials - A guide to product selection and specification. 2nd edition. John Wiley and Sons, Virginia, USA.

38. Sinha, A.; Kutnar, A., 2012. Green Building Rating System - Leadership in Energy and Environmental Design (LEED): Significance for wood industry. LesWood. 64(1/2): 1-5.

39. Todd, J.A.; Crawley, D.; Geissler, S.; Lindsey, G., 2001: Comparative assessment of environmental performance tools and the role of the Green Building Challenge. Build. Res. Inform. 29(5): 324-335 http://dx.doi.org/10.1080/09613210110064268.

40. Torcellini, P.A.; Deru, M.; Griffith, B.; Long, N.; Pless, S.; Judkoff, R., 2004: Lessons learned from the field evaluation of six high-performance buildings, in: ACEEE Summer Study on Energy Efficiency of Buildings, American Council for an Energy-Efficient Economy (Washington DC, USA): 3-325, 3-337. 
41. Trusty, W.; Horst, S., 2002: Integrating LCA Tools in Green Building Rating Systems. In Environmental Building News (Ed.), The Austin Papers: Best of the 2002 International Green Building Conference (pp. 53-57). Brattleboro VT: BuildingGreen Inc.

42. Trusty, W.; Meil, J.K., 1999: Building Life Cycle Assessment: Residential case study. Paper presented at the Mainstreaming Green, AIA Environment Committee conference on green building and design, Chattanooga, TN.

43. Trusty, W.; Meil, J.K.; Norris, G.A., (1998, October 1998). ATHENA: A LCA decision support tool for the building community. Paper presented at the Green Building Challenge '98, Vancouver.

44. Turner, C., 2006: LEED building performance in the Cascadia Region: a post occupancy evaluation report, 2006 (retrieved 18.09.08, from http://www.usgbc.org/ chapters/cascadia/docs/pdf/POE_REPORT_2006.pdf).

45. U.S. Environmental Protection Agency. (October 28, 2009). Green Building Basic Information. Retrieved December 10, 2009, from http:/www.epa.gov/greenbuilding/pubs/about.htm

46. United States Green Building Council (USGBC), 2009: New Construction and Major Renovation Reference Guide. USGBC, Washington D.C.

47. Van Oss, H.G.; Padovani, A.C., 2002: Cement manufacture and the environment. Part I: Chemistry and technology. J. Ind. Ecol. 6(1): 89-105 http://dx.doi.org/10.1162/108819802320971650.
48. Wadel, G., 2009: Sustainability in industrialized architecture: Modular lightweight construction applied to housing (La sostenibilidad en la construcción industrializada. La construcción modular ligera aplicada a la vivienda). Doctoral Thesis. Polytechnic University of Catalonia-Department of Architectural Constructions;. Available online at: http://www.tdx.cat/ TDX-0122110-180946.

49. Webster, 2005: Research Congress.

50. YPFPG, 2008: Assessing USGBC's Policy Options for Forest Certification \& the Use of Wood and Other Biobased Materials. A summary report prepared by the Yale Program on Forest Policy and Governance February 25, 2008.

51. Yudelson, J., 2009: “Green Building through Integrated Design.” Syracuse, NY: McGraw-Hill Publishing.

\section{Corresponding address:}

\section{Assistant Professor ANDREJA KUTNAR}

University of Primorska, Andrej Marušič Institute Muzejski trg 2, 6000 Koper, SLOVENIA

ILTRA d.o.o., Celovška cesta 268, 1000 Ljubljana,

SLOVENIA

e-mail: andreja.kutnar@upr.si 